$1-1-1890$

\title{
Meteorological report for September ; Reports of correspondents upon meteorology and crops for September
}

John A. Myers

Follow this and additional works at: https://researchrepository.wvu.edu/ wv_agricultural_and_forestry_experiment_station_bulletins

\section{Digital Commons Citation}

Myers, John A., "Meteorological report for September ; Reports of correspondents upon meteorology and crops for September" (1890). West Virginia Agricultural and Forestry Experiment Station Bulletins. 11.

https://researchrepository.wvu.edu/wv_agricultural_and_forestry_experiment_station_bulletins/11 @ WVU. It has been accepted for inclusion in West Virginia Agricultural and Forestry Experiment Station Bulletins by an authorized administrator of The Research Repository @ WVU. For more information, please contact ian.harmon@mail.wvu.edu. 
West Virginia University Libraries 



\section{BULL.TIN NO. 11}

OE THE

WEST VIRGINIA

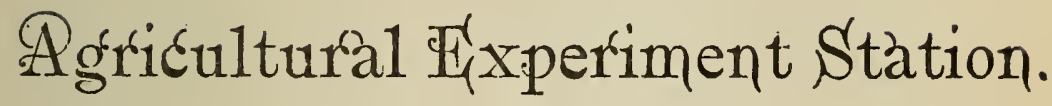
SFPT. 1890:

I. Meterological report for September.

II. Reports of Correspondents upon Meteorology and Crops for Septembe:

\section{BY JOHN A. MYERS,}

DIRECTOR.

The Director does not hold himself responsible for the opinions expressed by Correspondents.

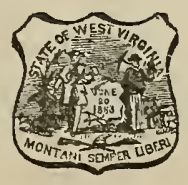

CHARLESTON :

Moses W. Donnliy, Poblic Prister. 
BOARD OF REGENTS OF THE WEST VIRGINIA UNIVERSITY.

District.

1. J. B SOMMERVILLE,

2. CLARENCE L. SMITH,

3. PEREGRIN HAYES,

4. D. D. JOHNSON,

5. JOHN G. SCHILLING,

6. EDWARD A. BENNETT,

7. WIRT A. FRENCH,

8. M. J. KESTER,

9. JAMES F. BROWN,

10. THOMAS J. FARNSWORTH,

11. JOSEPH MORELAND,

12. JOHN A. ROBINSON,

13. DR. W. W. BROWN,
P. O. Address.

Wheeling.

Fairmont.

Glenville.

Long Reach.

Spencer.

Huntington.

Princeton.

Union.

Charleston.

Buckhannon.

Morgantown.

Patterson Depot.

Kabletown.

\section{MEMBERS OF THE STATION COMMITTEE.}

JOHN A. ROBINSON, JOSEPH MORELAND,
JOHN G. SHILLING, THOMAS J. FARNSWORTH,

DR. W. W. BROWA

E. M. TURNER, LL. D., JOHN I. HARVEY.
Prasident of the University.

TrEASURER.

STATION STAFF.

JOHN A. MYERS, Рн. D., - - - - - Director H. R. BALDWIN, JR., - - - - - Chemist.

C. F. MILLSPAUGH, M, D., - Botanist and Microscopist. D. D. JOHNSON, A. M., - - - - Agriculturist. A. D. HOPKINS, - - - - - - Entomologist. SUSIE V. MAYERS, - - Stenographer and Book keeper. 


\begin{tabular}{|c|c|c|c|c|}
\hline & 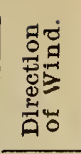 & $\frac{\frac{a}{a}}{\frac{a}{a}}$ & 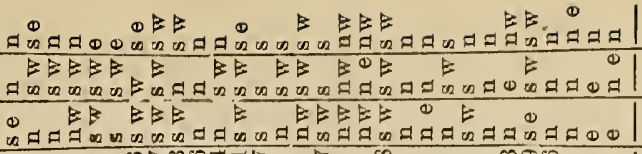 & \\
\hline & & & 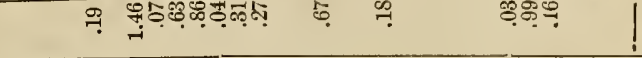 & \\
\hline & & - & बल नलनन्तक के न & \\
\hline & & क का & 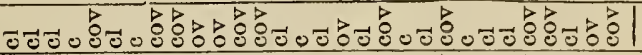 & \\
\hline & & ब品 & 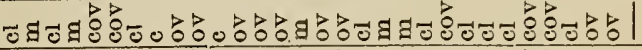 & \\
\hline & & नद्ध & 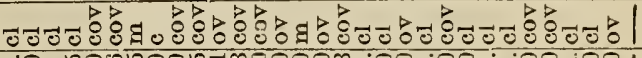 & \\
\hline & & 8 & 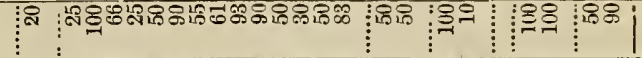 & \\
\hline & 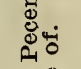 & कव्द & 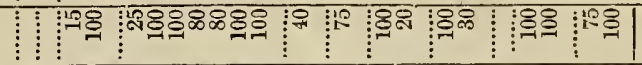 & \\
\hline & 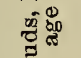 & क & 8) & \\
\hline & & a & । & \\
\hline ริ & & $\dot{8}$ & 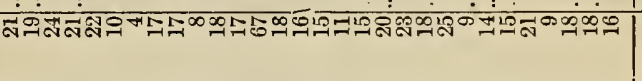 & : \\
\hline & & జึ & & \\
\hline 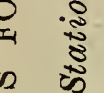 & בै: & 결 & Fin: & \\
\hline$\infty$ & 월 & .1 & 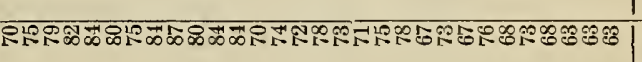 & $\dot{x \rightarrow n}$ \\
\hline & & 离 & & \\
\hline है & & 虽 & 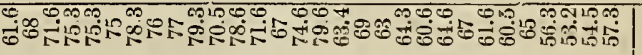 & \\
\hline & & कव & 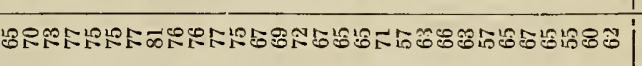 & \\
\hline & 跑 & क & 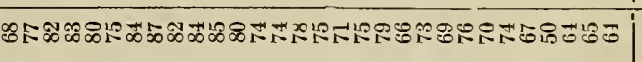 & \\
\hline$\simeq$ & & N- & 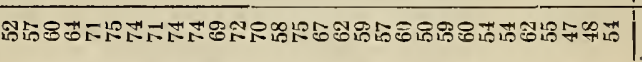 & \\
\hline & & $\mathbb{4}_{4}$ & 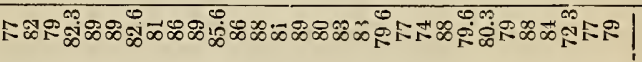 & \\
\hline & & क्व & ఐ & \\
\hline 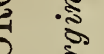 & 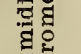 & ब告 & 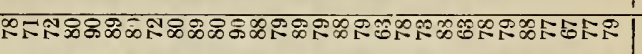 & \\
\hline & & N犃 & 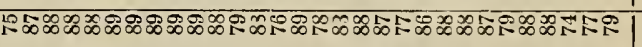 & \\
\hline & 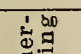 & $\infty \frac{9}{2}$ & 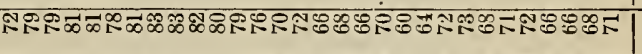 & \\
\hline & $\pi$ & क & 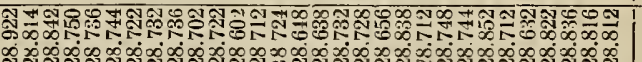 & \\
\hline & & बघ्ब & 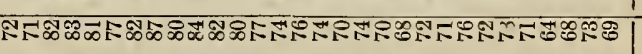 & \\
\hline & ( & a & 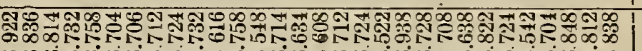 & \\
\hline & 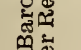 & $\approx$ & 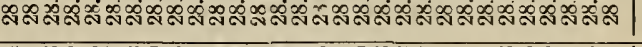 & \\
\hline & 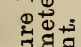 & Гद्धा & 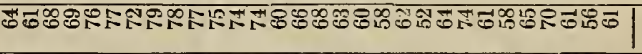 & \\
\hline & 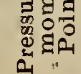 & $\therefore$ व & 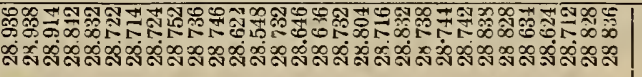 & \\
\hline
\end{tabular}


REPORT OF GEO. T. EGBERT.

RaVen's Eye, Fayette Co., W. Va.

For Month of September, 1890.

Have had frequent rains during the month. Corn up to the average. Buckwheat fair. Grass excellent. Delay in front has allowed corn to mature. Condition of live stock good. Market for cattle slightly improved, although the supply is far in excess of demand. Sheep scarce and high. No new enterprises beirg developed.

REPORT OF J. P. HALE.

Charleston, Kanawha Co., W: Va.

For Month of September, 1890.

Weather pleasant and seasonable. Rainfall a little more than average. No snow. Corn cropless than usual on account of late planting and too much wet weather for working. Wheat about three-quarter crop. Oats about ninety per cent. Barley and buckwheat non $\ni$ raised.. Grass above average. Fruit nearly a failure. Condition of live stock about average. M[arket about average. No new enterprises being developed. It is believed that Alfalfa or Mexican clover would do well here but has not been tried.

\section{REPORT OF S. A. HOUSTON.}

Pickatway, Monroe Co., W. Va.

For Month of September, 1890.

Weather very dry, only one decent shower. Condition of corn one half crop. Wheat one-half crop. Grass in some parts of county burnt up. Oats one-third crop. No fruit. No barley raised Buckwheat very much irjured. Stock not as fat as usual at this season; troubled to some extent by horn fly. Market low. Oreamery and Improved Mills are the new enterprises here. The principal farming industry is stock raising. It does not pay to raise a surplus of any crop at present prices. 
REPORT OF EUGENE BAKER.

Letetown, Jefferson Co., W. VA.

For the Month of September, 1890.

Weather cool with slight rain. Corn not up to the average. Wheat about average. Grass lnoking well. Began seeding wheat about September 2 lst and cutting corn at the same time. Very few apples. grapes or pears. No peaches. All kinds of stock looking fairly well and seem to be in healthy condilion. Market slow. A canning factory about to be established and the ore beds are soon to be worked, are the new enterprises being developed. The principal farming industries are grain and stock raising, creameries, canning factories and the raising of tobacco. Our county fair showed an increase in machinery, live stock and farm products.

REPORT OF W. E. KISEN.

Frantin, Pendleton, Co., W. Va.

For the Month of September, 1890.

The weather has been fino, with plenty of rain. Corn one-half crop. Wheat one-half crop. Oats light. Buckwheat, light, not more than one-half crop. Grass good, above average. Fruit entire failure. Cattle in good condilion, prices low. Horses in good condition, no demand. Sheep, prices good. Swine scarce and bigh. Poultry acarce. No new enterprises, but there is a company now being organized to boom the county. Stock raising the principal farming industry.

REPORT OF R. A. ALEXANDER.

Charlestown, Jefferson Co., W. Va.

For Month of September, 1880.

Weather moderate. Corn, wheat and grass very guod. Live stock in fine condition. Market fair. The Land Improvement Company is the only new enterprise being developed. Wheat and corn are the principal farming industries. and I think our county as well adapted for raising tobacco as Lancaster county, Pennsylvania, if the farmers can be induced to try the experiment.

REPORT OF LEE H. MOLER.

Moler's, Jefferson Co., W. Va.

For Month of September, 1890.

Condition of weather wet and murky. More than one-half 
the time have had rainfall. Corn fair, average crop. Wheat not up to average yield. Fall pasturage in excellent condition. Cattle, \&c., in prime condition, except distemper in mild form in certain localities among the horses. Some little demand for cattle and horses. Sheep scarce and in demand. The principal farming industries are wheat and corn.

\section{REPORT OF ADAMI FISHER.}

\section{Moorefield, Hardy Oo., W. Va.}

For the Month of September, 1890.

Condition if the weather warm and rainy. Corn about balf crop, say twenty five bushels per acre on river bottom; hills very little. Uats light. Hay abundant and good. Fruit none. Oondition of stock good. Sheep in demand Other stock dull. No diseases among them. A large tannery will be built near Moorefield at once. It is the only new enterprise. The principal farming industries are corn, hay and stock raising.

\section{REPORT OF S. R. HANEN.}

Glen Easton, Marshall Co., W. Va.

For Month of September, 1890

Weather bad. Unfavorable for work. Excessive rainfall for September. Oorn about 65 per cent. Droughts in July, damaaged by wind in August and rain in Septembor. No wheat sowel yet. H'ruit crop entire failure. Grass abundant. Condition of live stock good generally. Sheep in demand with good prices offered. Horses fair price Swine fair, average price. Oattle, thrifty, but prices low. The principal farming industries are in raising corn, wheat, oats and hay.

\section{REPORT OF W. A. MORGAN.}

Shepherdstown, Jefferson Co., W. Va.

For the month of September, 1890.

The weather has been unusually warm with frequent rains. The corn is now being cut. It shows a good croo from the appearance in the field; it seems to bo well matured and stand well in the shocks. Live stock in good condition. The market for cattle and hogs good, and for sheep too, but supply is insufficient to demand. Pasture in fine condition. The old "Shanondale Springs," a watering place, has been rebuilt recently as a summer resort. The only enterprise developed since last report. Wheat, 
corn, oats and potatoes, \&c, are the principal farming industries, and the prices are better than usual. Farmers feel encouraged at the prospect of hetter prices and better legislation for them in the future.

\section{REPORT OF J. W. CARTER.}

Pleasant Dale, Hampshire Co., W. Va.

For the Month of September, 1890.

Weather seasonable. Quantity of rain above average. Quite warm. No frost yet. Corn well matured. About one-half crop. Buckwheat will make about three-quarter crop. Pasture good. Condition of live stock good. Some poultry have cholera. Market good for large horses. Cattle dull. Sheep scarce and high. Swine active. Poultry brings good prices. The building of a large Roller Flouring Mill, Sash Factory and Woolen Mill at Romney is now being contemplated by the Romney Land Improvement Company.

REPORT OF A. W. WESTFALL.

Auburn, Ritchie Co., W. Va.

For Month of September, 1890.

A great deal of rain fell during the month. Corn in a much better condition than was expected a month ago. Buckwheat almost an entire failure. Grass good. Fruit in a bad condition. Stock of all kinds in a fair condition. No diseases attacking them. Market good for horses, sheep and poultry. Market for swine fair, but not as good as this time last year. The new enterprises being developed in our county are lumber and oil business. The principal farming industries are grain and stock raising. In short the county is in as good condition as could be expected. 
